\title{
The changing trends in education
}

\author{
Leman Figen Gül* \\ Department of Architecture, Istanbul Technical University, Istanbul, Turkey
}

\section{Edited by:}

Xiaoxun Sun, Australian Council for Educational Research, Australia

Reviewed by:

Gabriella Agrusti, LUMSA University, Italy

Hua Wang, Victoria University,

Australia

\section{${ }^{*}$ Correspondence:}

Leman Figen Gül, Department of

Architecture, Faculty of Architecture,

Istanbul Technical University, Taskisla,

34367 Harbiye, Sisli Istanbul, Turkey

e-mail: leman.gul@uni.sydney.edu.au
With the recent developments in information and communication technologies (ICTs), there is a significant change in our daily life. Eventually, integrating ICTs into teaching and learning offers significant potentials for higher education institutions and new challenges for educators, through their capacity to facilitate new kind of education in the digital environments. As a result, there have been significant changes in several professions' curricula such as design, business, medicine, and engineering., to accommodate new demands, opportunities, processes, and potentials provided by digital media and computational tools.

Keywords: digital education, virtual environments, design education, curriculum design, collaborative learning
With the recent developments in information and communication technologies (ICTs), there is a significant change in our daily life. Most of us have become very much dependent on the technology $-78.3 \%$ of the developed world's population and $32.4 \%$ of the developing world's population are the Internet users and, those figures are increasing every year (International Telecommunication Union; http://www.itu.int/en/ITU-D/ Statistics/Pages/default.aspx). Eventually, integrating ICTs into teaching and learning offers significant potentials for higher education institutions and opens new challenges for educators, through their capacity to facilitate new kind of education in the digital environments. Consequently, significant changes occurred in several professions' curricula such as design, business, medicine, and engineering. to facilitate new requirements, projections, processes, and possibilities provided by advance digital tools.

Research in educational use of digital environments delivers convincing evidence of the potentials of the emerging digital platforms to assist more effective learning. One of the main advantages of digital education identified is that digital teaching platforms offer students data-rich, online, synthetic environments, enabled with media, information, and communication tools. In such platforms, students become virtual characters (avatars) who immersed into virtual reality to collaboratively work and learn. In order to enhance their learning capacity, students should be given opportunities for exploration and manipulation within the environment as well as opportunities for discourse between students (Dickey, 2007). Similarly, this new learning and teaching environment provides teachers possibilities to built constructive environments in which knowledge is obtained and learning is an active process.

Teaching in digital environments can take many forms including didactic teaching, active learning, collaborative learning, gaming, simulations, etc. Working and articulating ideas in a group context, questioning and challenging each others' ideas, and engaging in total collaboration in the determination of design problems make learning most effective.

Winn (1993) identifies the following approaches in digital education. The first approach is based on behavior theory that transforms the conventional approaches to the instructional design (Dick and Carey, 1985; Gagne et al., 1988): (1) forecasting students' behavior (Reigeluth, 1983); (2) decreasing essential knowledge and skills by operating proper analytical techniques (Landa, 1983); and (3) adapting a set of actions to confirm that without the additional help of the teachers or designers, the application would work successfully (Winn, 1993).

Second, it is important the ways of information that are offered to students (Fleming and Levie, 1993). In this approach, processing information and the learning material have a greater impact rather than on task reduction and determination of instructional strategies on the basis of the content (Winn, 1993).

Psychologists recognize that cognitive theories of learning and instruction require the foundations for instructional designers to determine assistance rather than behavioral theory (Winn, 1993).

Cognitive theories are adapted as the third approach. The basic principle is that the ways of how the interaction between the students and instruction occurred has greater importance than the content or how information is presented (Winn, 1993). The cognitive theory (Anderson, 1976, 1983) formulated the basis of "intelligent" computer-based tutors as follows:

- The objective structure of the problem space must be identified; - The guidance in the context of problem-solving must be provided;

- The instant feedback on errors must be provided;

- The load of the working memory must be minimized;

- Modifying the "grain size" of instruction with learning to facilitate the knowledge gathering process; and

- Empowering the student to reach the required skills by sequential estimation.

The final one depends on determining the ways students interact with courseware. The approach is based on the assumption of knowledge construction that is built by the students themselves, not provided through the course material (Winn, 1993). According to this view, the knowledge is constructed, not transferred, and the students dynamically learn (Jonassen, 1999). Within this context, students are given opportunities to apply new knowledge 
and skills in a collective setting (Gül et al., 2007). Furthermore, the role of teachers is "to help and guide the student in the conceptual organization of certain areas of experience" (Glasersfeld, 1983).

To support the intention of integration of digital environments in education, we have developed several collaborative virtual studios over the years: (1) designing virtual worlds and global teamwork (collaboration between The University of Sydney-Australia and Istanbul Technical University-Turkey in 2007 and 2008) (Gül et al., 2007, 2008), (2) NU Genesis (collaboration between the University of Newcastle-Australia and Rangsit University-Thailand) (Gu et al., 2009). As discussed earlier, we have adopted Winn's (1993) teaching approach that depends on the understanding of students' interaction with the course material considering the students as the active learners. In design teaching context, the main concern is to teach the theory and applications in designing of artifacts that accommodate human activities. Incorporating the digital environments into design education, the principle of teaching process is not changed but there are some additional concerns needed to be considered. For example, our teaching experience shows that in order to achieve the best outcome in the collaborative virtual design studio, constructing a shared goal, and an understanding of the given problems are essential for students. In addition, we have outlined several crucial factors in order to enhance students' learning: (1) focusing on active learning; (2) focusing on the learner through the relevance of the content; (3) developing clear objectives to provide direction to student learning; (4) articulating knowledge and learning experiences; (5) ensuring the application of effective feedback mechanisms; (6) employing effective "scaffolding" in the organization of the learning experiences; and (7) encouraging collaborative learning (Gül et al., 2012).

Our digital teaching experience confirms that the virtual design studio and digital platforms provide an outstanding environment for learners. Particularly, digital education platforms support collaborative learning and co-design situations in which students develop a mutual understanding of the given design problem and a shared goal, and achieve this goal through working and learning together on the design artifact. This design artifact becomes the ground on which the collaboration, negotiation, conflicts, and critiques occurred (Gül et al., 2012).

In order to enhance this fundamental subject, we pursue papers that provide theoretical or empirical contributions to the role of advanced digital technologies in education. Digital education specialty section of Frontiers in ICT will be devoted to original papers, concerned with the challenge of new emerging educational paradigms of emerging digital technologies.

The principal aim of this special section on technologies for teaching is to provide further discussion at the intersection of theory and practice. Related topics to the application or reflection of digital technologies in education, which may include, but are not limited to, are welcome:

- Frameworks for teaching with emerging technologies;

- Curriculum development;

- Assessment of knowledge and skills;

- Collaborative learning in digital environments;

- Facilitating learning utilizing digital spaces;
- Ideation and virtuality;

- Multi-disciplinary and multi-cultural collaboration in education; and

- Supporting student learning in a media-rich environments.

\section{REFERENCES}

Anderson, J. (1976). Language, Memory and Thought. Hillsdale, NJ: Erlbaum Associates.

Anderson, J. (1983). The Architecture of Cognition. Cambridge, MA: Harvard University Press.

Dick, W., and Carey, L. (1985). The Systematic Design if Instruction. Glenview, IL: Scott Foresman.

Dickey, M. D. (2007). Teaching in 3D: pedagogical affordances and constraints of 3D virtual worlds for synchronous distance education. Dist. Educ. 24, 105-121. doi:10.1080/01587910303047

Fleming, M. L., and Levie, W. H. (1993). Instructional Message Design: Principles from the Cognitive and Behavioral Science. Hillsdale, NJ: Educational Technology Publications.

Gagne, R. M., Briggs, L. J., and Wager, W. W. (1988). Principles of Instructional Design. New York, NY: Holt Rinehart and Winston.

Glasersfeld, E. V. (1983). "Learning as constructive activity," in Proceedings of the 5th Annual Meeting of the North American Group of PME, eds J. C. Bergeron and N. Herscovics (Montréal, QC: PME-NA), 41-101.

Gu, N., Gül, L. F., Williams, A., and Nakapan, W. (2009). “Conquering new worlds,” in Proceedings of the 14th International Conference on Computer Aided Architectural Design Research in Asia/Yunlin (Taiwan), Between Man and Machine? Integration, Intuition, Intelligence 2009 (Taiwan), 153-164.

Gül, L. F., Gu, N., and Maher, M. L. (2007). "Designing virtual worlds: a case study of design education in and of 3D virtual worlds," in 2007 Proceedings of ConnectED 2007, International Conference on Design Education, 9-12 July, eds Z. Robert and R. Cart (Sydney, NSW: The University of New South Wales).

Gül, L. F., Gu, N., and Williams, A. (2012). "Constructivist learning theory in virtual design studios," in Computational Design Methods and Technologies: Applications in CAD, CAM and CAE Education, Chap. 9, eds N. Gu and X. Wang (Hershey, PA: IGI Global), 139-162.

Gül, L. F., Wang, X., Bülbül, T. T., Çagdas, G., and Tong, H. (2008). “Global teamwork: a study of design learning in collaborative virtual environments," in Design Research Society 2008 Conference, DRS 2008, Undisciplined! (Sheffield: Sheffield Hallam University).

Jonassen, D. H. (1999). “Designing constructivist learning environments," in Instructional Design Theories and Models, ed. C. M. Reigeluth (Mahwah, NJ: Erlbaum Associates), 215-239.

Landa, L. (1983). “The algo-heuristic theory of instruction," in Instructional Design Theories and Models, ed. C. M. Reigeluth (Hillsdale, NJ: Lawrence Erlbaum Associates), 163-211.

Reigeluth, C. M. (1983). Instructional Design: What Is It and Why Is It? Hillsdale, NJ: Lawrence Erlbaum Associates.

Winn, W. (1993). A Conceptual Basis for Educational Applications of Virtual Reality. Seattle, WA: Human Interface Technology Laboratory, Washington Technology Center, University of Washington.

Conflict of Interest Statement: The author declares that the research was conducted in the absence of any commercial or financial relationships that could be construed as a potential conflict of interest.

Received: 13 November 2014; paper pending published: 03 December 2014; accepted: 11 January 2015; published online: 03 February 2015.

Citation: Gül LF (2015) The changing trends in education. Front. ICT 2:1. doi: 10.3389/fict.2015.00001

This article was submitted to Digital Education, a section of the journal Frontiers in ICT.

Copyright $(2) 2015$ Gül. This is an open-access article distributed under the terms of the Creative Commons Attribution License (CC BY). The use, distribution or reproduction in other forums is permitted, provided the original author(s) or licensor are credited and that the original publication in this journal is cited, in accordance with accepted academic practice. No use, distribution or reproduction is permitted which does not comply with these terms. 